\title{
An Empirical Analysis of RMB Exchange Rate Pass-Through Effect in Yunnan Province
}

\author{
Yili $\mathrm{Hu}^{*}$ \\ School of Economics, International Business School \\ Yunnan University of Finance \& Economics \\ Kunming, China \\ 495920873@qq.com
}

\author{
Haoran $\mathrm{Wu}$ \\ International Business School \\ Yunnan University of Finance \& Economics \\ Kunming, China \\ 846054496@qq.com
}

\begin{abstract}
In microeconomics, the exchange rate pass-through effect does not only affect the pricing of products and production adjustment of the enterprises involved in international trade, but also has significant implications for the decision-making of consumers. This paper analyses the mechanism of exchange rate change to the price level in theory. A VAR model is used to test the relationship among the RMB nominal effective exchange rate, CPI, PPI, M2, the industrial value added and the oil price in Yunnan Province. The results show that there is a long-term cointegration relationship among these variables and in the medium- and short-term the exchange rate change has a negative impact on CPI and PPI. They imply that the appreciation of RMB exchange rate leads to the decline in the price of consumer goods and industrial products. Based on the results, some suggestions are put forward: the local government should upgrade and update industrial products; the local government should encourage the business in Yunnan to strength the competitiveness of products.
\end{abstract}

Keywords—pass-through effect; exchange rate; CPI; PPI

\section{INTRODUCTION}

The relationship between RMB exchange rate and price change has always been a hot topic in the economic development of China. In June 2010, the reform of exchange rate regime was implemented again in China. After that, RMB continued to appreciate. According to the traditional passthrough theory of exchange rate, RMB appreciation should be able to effectively alleviate China's huge balance of net export and inflation. However, after the reform China's export continued to increase substantially, which has caused the further expansion of net export, as shown in the Fig. 1.

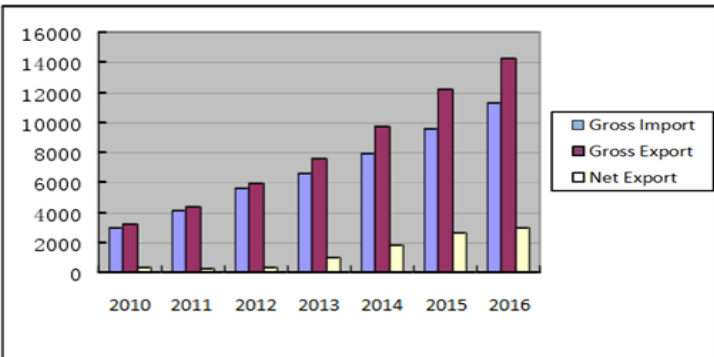

Fig. 1. Trade Balance in China.
Influenced by the level of economic development, the passthrough effect of exchange rate to prices in various regions is different. As an inland province in China, Yunnan is not very sensitive to the change of foreign trade. Therefore, starting from the study of the pass-through effect of RMB exchange rate on price in Yunnan, this dissertation verifies if $\mathrm{RMB}$ exchange rate change can affect regional prices in China, as well as the pass-through degree of RMB exchange rate in an inland province.

The structure of the content is as follows: the second part is literature review; the third part mainly introduces the mechanism of RMB exchange rate pass through to regional prices; the fourth part describes the data; the fifth part makes an empirical analysis on the data using a VAR model; the last part draws the conclusion and puts forward some suggestions.

\section{LITERATURE REVIEW}

In an open macro-economy, exchange rate pass-through is complete, and exchange rate fluctuation will cause completely reverse change in price. The famous theory is the purchasing power parity: the nominal exchange rate and price in a country change in the opposite direction, and the nominal exchange rate has the "expenditure pass-through" effect on price. However, the effectiveness of the theory of purchasing power parity is doubtful. Devereux and Yetman presented that there is a positive and nonlinear relationship between the exchange rate pass-through effect and domestic inflation [7]. Exchange rate pass-through effect is affected by the volatility of exchange rate. When the volatility of exchange rate is large, exchange rate pass-through effect will increase. Devereux, Engel and Storgaard built an endogenous model of exchange rate passthrough in the open macro-economy to find that the level of variance in the monetary growth rate determines the passthrough degree of exchange rate [8]. Countries with small volatility in monetary growth rate have less exchange rate passthrough effect.

In the 1990s, the coexistence of devaluation of domestic currencies and increase of inflation occurred in a great number of countries in the world. This abnormal phenomenon promoted researchers to seek a reasonable interpretation of incomplete exchange rate pass-through. Taylor stated that under the condition of low inflation [15], enterprises strive to maintain the product prices, and the pass-through effect of

*Corresponding author 
exchange rate will be reduced. Choudhri and Hakura also found that low inflation will reduce corporate expectations of prices and affect the effect of exchange rate pass-through [6]. Based on the premises that foreign exporters sell intermediate products to domestic manufacturers and domestic manufacturers sell intermediate products to consumers, Bacchetta and Wincoop demonstrated the possibility of exchange rate's complete pass-through to import prices and zero pass-through to consumer price index. The results showed that the pass-through of exchange rate to consumer price index was more limited than its pass-through to import prices [1].

Relevant empirical research has been gradually enriched. Faruqee used a VAR model to find that in the sample time period [10], all the price chains were less affected by shortterm exchange rate shock, but with the passage of time, the price pass-through effect of exchange rate has been gradually increasing. Besides, he found that the exchange rate has small pass-through effect on wages and consumer price index, but has relatively large pass-through effect on import price. He believed that the asymmetry of corporate pricing behavior and the difference of distribution cost are related to the passthrough effect. In the Euro area, import commodities are priced by the consumer currency, and export commodities are priced by the producer currency. Michele, Elke and Marcelo [14] used a VAR to find that in 12 emerging market countries, the exchange rate pass-through is positively related to inflation. Bahmani-Oskooee and Fariditavana applied a non-linear ARDL approach to find that the pass-through effect of exchange rate is nonlinear [2].

Chinese scholars are more inclined to empirical studies of exchange rate pass-through. By applying the error correction model (ECM), co-integration test and Phillips-Hansen complete correction estimation in the semi-open economic framework, Bu studied the exchange rate pass-through effect, and concluded that the change in exchange rate has a significant impact on producer price index (PPI) and retail price index (RPI) [4]. In the long run, the effect of exchange rate change on PPI and RPI is more obvious, but in the short run, RPI is less sensitive to the fluctuation of exchange rate. Chen and Liu used a recursive vector autoregressive model (RVAR) to find that the pass-through effect of the RMB effective exchange rate has little influence on China's import price and CPI [5], the difference in the pass-through effects of $\mathrm{RMB}$ effective exchange rate on import price and CPI only is the pass-through speed, not the pass-through extent, and stable monetary policy can to some extent repress the pass-through effect of exchange rate on domestic price. They presented their viewpoint that China's trade surplus cannot be solved by RMB appreciation, and the control of inflation cannot be carried out by the dollar peg. Jin and Wang stated that the pass-through effect of nominal effective exchange rate of RMB on domestic consumer price index is low [13]. Zhu and Yu presented that the change of exchange rate cannot explain the reason of inflation in domestic currency [17]. Wang and Li found that China's domestic price level is significantly influenced by the price level of major trading partners of China [16]. Feng stated that there is a significant difference in the exchange rate passthrough effect among different industries [11]. Fan and Xiang demonstrated that the influence of RMB nominal exchange rate on the fluctuation of import prices and domestic prices is limited, and it is not the main reason for the fluctuation of domestic prices [9]. Bi and Zhu used a co-integration test and an ECM to find that the pass-through of RMB exchange rate changes to domestic consumer price was incomplete [3], the pass-through process had time lag, and the elasticity of import price to RMB exchange rate was far higher than that of consumer price to $\mathrm{RMB}$ exchange rate. In addition, $\mathrm{Hu}$ and $\mathrm{Li}$ compared the difference on the pass-through effect in the time periods of ante- and post-reform [12]. They took the first reform of exchange rate regime in July 2005 as the threshold. And they found that after this reform, the producer price was significantly influenced by the change of RMB exchange rate, while the consumer price was less influenced; after January 2008 , the impact of exchange rate had a great contribution to the reduction of domestic inflation.

Most of the existing papers basically studied exchange rate pass-through effect on the whole country, and few studies of exchange rate pass-through effect on regional price are conducted. Many literatures have obtained the different results, but in-depth and systematic research on the pass-through mechanism is lacking. Furthermore, many papers conducted study in a long time interval, and the economic environment and economic structure may change during the period, thus leading to inaccuracy of the research. Finally, there is a difference between long-term effect and short-term effect and the difference was not taken into account in many papers. This paper will make up for the defects in previous studies through more detailed analysis.

\section{THEORETICAL ANALYSIS}

The pass-through mechanism of exchange rate on domestic price is mainly performed through direct and indirect channels. The domestic price is mainly represented by the consumer price index (CPI) and the producer price index (PPI), and the specific pass-through path is shown in Fig. 2.

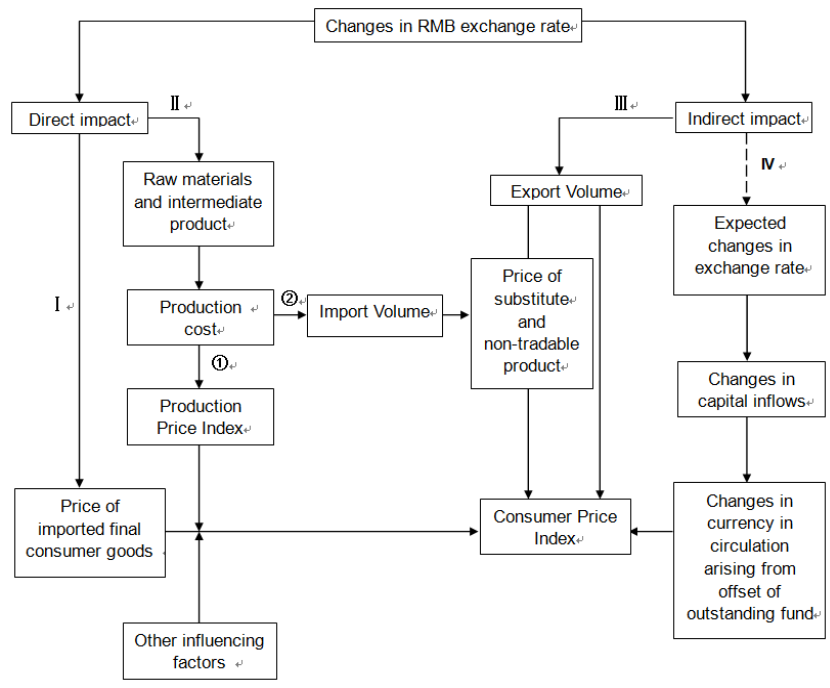

Fig. 2. Pass-Through Path of RMB Appreciation to Domestic Price. 


\section{A. Direct Influence}

1) Pass-through path I: From the price of imported consumer goods to CPI.

In this path, the exchange rate affects the domestic price level by affecting the price of imported consumer goods. Under the condition of perfect competition, the pass-through effect of exchange rate on imported consumer goods is $100 \%$. However, due to the existence of monopoly competition, pricing of firms and transportation cost, the pass-through of exchange rate to imported consumer goods is incomplete. If the import industry of a country has a high degree of monopoly in the international market, the power on pricing by importers is strong and the transportation cost of the imported goods is high, the passthrough effect of imported goods will be low. The exchange rate pass-through effect is inversely proportional to the degree of monopoly on a country's import, the power on pricing by importers and the transportation cost. The degree of the influence on domestic price depends on the proportion of the imported consumer goods in the total consumption of domestic residents. The more the consumption of a country depends on imports, the greater the influence of exchange rate change on domestic price will be.

2) Pass-through path II: From the price of imported intermediate goods and raw materials to PPI and CPI.

Exchange rate affects the price of imported intermediate goods and raw materials, thereby affecting the domestic price. In pass-through path II, the exchange rate change can affect CPI through direct channel (1) and indirect channel (2). Herein, direct channel (1) is analyzed, and indirect channel (2) will be analyzed in pass-through path III.

The influence of exchange rate changes on imported intermediate products and raw materials is similar to that on imported consumer goods. The price of imported intermediate products and raw materials is only part of the cost of finished goods, and the influence degree of exchange rate change on production cost is determined by the proportion of the price of the imported intermediate products and raw materials in the total cost. The greater the proportion of the price of imported intermediate products and raw materials in total production cost is, the greater the influence of exchange rate change on the production cost will be. The influence of exchange rate on production cost will further affect the producer price index, and ultimately affect the domestic price level through substitution of goods, inflation and wage stickiness.

\section{B. Indirect Influence}

1) Pass-through path III: From import-export volume to CPI.

Exchange rate change will change the structure of consumer goods, and ultimately affect total domestic demand and supply, and further affect the domestic price. Specifically, the influence of exchange rate change on domestic price is manifested in two aspects: First is export. Exchange rate change will lead to change in the price of exports, thereby affecting the competitiveness of exported commodities and causing the transformation of some commodities from export to domestic sale. These commodities for domestic sale will break the balance of supply and demand, and change the price level of the initial exported commodities, substitutes and nontraded goods, thus eventually affecting the domestic general price level. Moreover, in the theory of elasticity the change of exchange rate will affect the amount of exported commodities, thereby changing the aggregate demand. Further, on the condition of sufficient supply, the change of the aggregate demand will affect residents' income, and the residents' income will determine the price level of commodities, thus eventually affecting the domestic general price level. Second is import. The influence in terms of import mainly comes from branch (2) of path II. Exchange rate change will directly affect the price of imported intermediate products and raw materials, thereby affecting the production cost and the price of finished products. This will change the relative price among finished products, trade substitutes and non-tradables, and change the demand and supply and prices of the trade substitutes and nontradables, thereby ultimately affecting the domestic price level.

2) Pass-through path IV: Change of RMB appreciation expectation.

This path mainly affects the domestic price by changing the money supply. The fluctuation of exchange rate will cause the change in the capital inflow into the domestic market. In order to avoid threat by the large unexpected capital inflow on the stability of domestic economy, the government adjusts the money supply. The reverse offset by the adjustment of money supply affects the domestic price.

Based on the above theoretical analysis, the hypothesis in this paper is proposed, that is, RMB exchange rate change has an exchange rate pass-through effect on regional price in Yunnan Province.

\section{DATA DESCRIPTION}

The price level in Yunnan Province has experienced three stages since 2002: price inflation between 2002 and 2004, price deflation between 2005 and 2010, and modest price rise between 2011 and 2016 (Data from the CSMAR):

Stage 1 is the period of price inflation between 1993 and 2004. All the price indexes hit new highs, leading to inflation. The inflation between 1993 and 2004 was mainly attributed to the excessive expansion of investment and credit. According to statistics, government investment and monetary supply grew by $24 \%$ and $30 \%$ separately in 2002 .

Stage 2 the period of price deflation between 2005 and 2010: Yunnan Province was mired in deflation in this period. The deflation was mainly attributed to the decline in investment demand caused by credit crunch and the insufficient intrinsic motivation for investment growth caused by the financial crisis in 2008.

Stage 3 the period of modest price rise between 2011 and 2016: Yunnan's economy entered a new period of rapid growth, and domestic prices began to rise moderately.

In the first stage, nominal effective exchange rate appreciated continuously while price level continued to decline In the second stage, nominal effective exchange rate fell while price indexes rose. In the third stage, both nominal effective exchange rate and domestic prices rose, causing the issue of 
internal devaluation and external appreciation. Since there was no negative correlation between exchange rate and price level in this period, empirical tests were carried out for further analysis.

\section{DATA ANALYSIS}

This paper uses a dynamic VAR model. The variables selected include international crude oil price CO, Yunnan's producer price index PPI, Yunnan's consumer price index CPI and RMB nominal effective exchange rate NEER. Wherein, Yunnan's producer price index PPI and consumer price index CPI serve as the proxy indicators of price levels for production and consumption in Yunnan Province. RMB nominal effective exchange rate NEER, international crude oil price $\mathrm{CO}$ and total social financing M2 are used as the indicators of the exchange rate, supply shock and monetary shock separately. The CPI and PPI data is fixed-base data, converted from year-on-year comparisons and month-on-month data, with the year 2009 as 100. The nominal effective exchange rate NEER, which is the nominal effective exchange rate in International Monetary Fund's International Financial Statistics, adopts indirect quotation. $\mathrm{CO}$ data were derived from the monthly average price of Brent futures respectively. All the price indexes, industrial added value and total social financing were seasonally adjusted by X12.

\section{A. ADF Unit Root Test}

This paper selects ADF unit root test to judge the stability of data. The results of table 1 show that all variables are firstorder stationary. Therefore, variables included in the model are DCPI, DPPI, DVAI, DM2, DNEER and DCO in the VAR model. It is necessary to further consider lag structure of the model after corresponding variables are selected.

TABLE I. UNIT ROOT TEST OF THE VARIOUS VARIABLES

\begin{tabular}{|l|l|c|}
\hline \multicolumn{3}{|c|}{ Unit Root Test } \\
\hline Variables & \multicolumn{1}{|c|}{ ADF value } & Probability \\
\hline CPI & 0.062390 & 0.9609 \\
\hline DCPI $^{\mathrm{a}}$ & $-9.458769^{* * *}{ }^{\mathrm{b}}$ & 0.0000 \\
\hline PPI & -1.612095 & 0.4720 \\
\hline DPPI & $-7.284120^{* * *}$ & 0.0000 \\
\hline VAI & -2.026191 & 0.2753 \\
\hline DVAI & $-6.247260^{* * *}$ & 0.0000 \\
\hline M2 & -0.308562 & 0.9182 \\
\hline DM2 & $-8.646255^{* * *}$ & 0.0000 \\
\hline NEER & -1.021236 & 0.7425 \\
\hline DNEER & $-6.649413^{* * * *}$ & 0.0000 \\
\hline CO & -1.924145 & 0.3198 \\
\hline DCO & $-6.023246^{* * *}$ & 0.0000 \\
\hline & ${ }^{\mathrm{a}}$ D represents first-order differential of raw data. \\
\hline b*** represents $1 \%$ of significance level.
\end{tabular}

\section{B. Co-Integration Test}

Table 2 demonstrates the values of LR, AIC and SC under different lag orders in VAR models. The results show that AIC is the smallest when the lag order is 2 while SC is the smallest when the lag order is 1 . In this case, the lag order should be selected in accordance with LR. The appropriate lag order is 2.

TABLE II. UNIT ROOT TEST FOR MODEL WITH FIRST-ORDER LAGS

\begin{tabular}{|c|c|c|c|}
\hline Lags & LR & AIC & SIC \\
\hline 0 & NA & -19.10857 & -18.93442 \\
\hline 1 & 21.01281 & -21.51905 & $-20.76269^{*}$ \\
\hline 2 & $108.4721^{\text {a }}$ & $-21.68456^{*}$ & -19.95167 \\
\hline 3 & 24.72894 & -21.68423 & -19.42057 \\
\hline 4 & 17.29067 & -21.63346 & -18.72362 \\
\hline
\end{tabular}

After the lag order was set, a VAR model with two lags was established and Johansen co-integration test was carried out. The test results show that there is at least one cointegration relationship.

The co-integration equation is:

DCPI $=0.5692 D P P I+0.0688 D V A I+0.0075 D C O+0.1185 D M 2-0.0902 D N E E R$

$$
\begin{array}{lllll}
(0.1003) & (0.0145) & (0.0074) & (0.0251) & (0.0344)
\end{array}
$$

The long-term co-integration relation shows that PPI has the greatest impact on CPI in the long run, followed by M2, NEER and VAI. The reason is that long-term impact of PPI on CPI includes the impact of M2, NEER and VAI on PPI to some extent, since M2, NEER and VAI influence both CPI and PPI. The coefficient of NEER is -0.0902 , which indicates that every $1 \%$ increase in $\mathrm{RMB}$ exchange rate shall decrease $\mathrm{CPI}$ by $0.0902 \%$.

\section{Co-integration Stability Test}

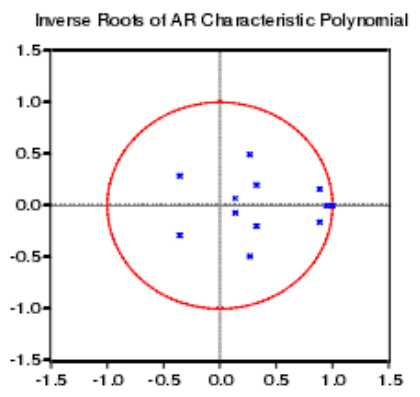

Fig. 3. AR Root Test on the VAR Model

As is described in Fig. 3, all the inverse roots of all eigenvalues of the VAR model are within the unit circle. It means that the VAR model is stable and the impulse response is valid.

\section{Impulse Response}

Cholesky decomposition order is of great significance to the analysis of impulse response. It directly influences the impact degrees. Generally, variable that has greater sustainable 
impact on other variables and is less influenced by other variables ranks higher, based on which the Cholesky decomposition order is determined. According to the result of Response to Cholesky One S.D. Innovations \pm 2 S.E., the Cholesky decomposition order is:

$$
\mathrm{CO} \rightarrow \mathrm{NEER} \rightarrow \mathrm{VAI} \rightarrow \mathrm{M} 2 \rightarrow \mathrm{PPI} \rightarrow \mathrm{CPI}
$$

In order to test the response of CPI and PPI to change in different factors, this paper takes the impulse response to show the short-term response of CPI and PPI. The results of impulse response for other factors in the VAR model are eliminated due to the irrelevance of the results with the target in this paper. This paper focuses on the impulse response of CPI and PPI to change in other factors in the VAR model.
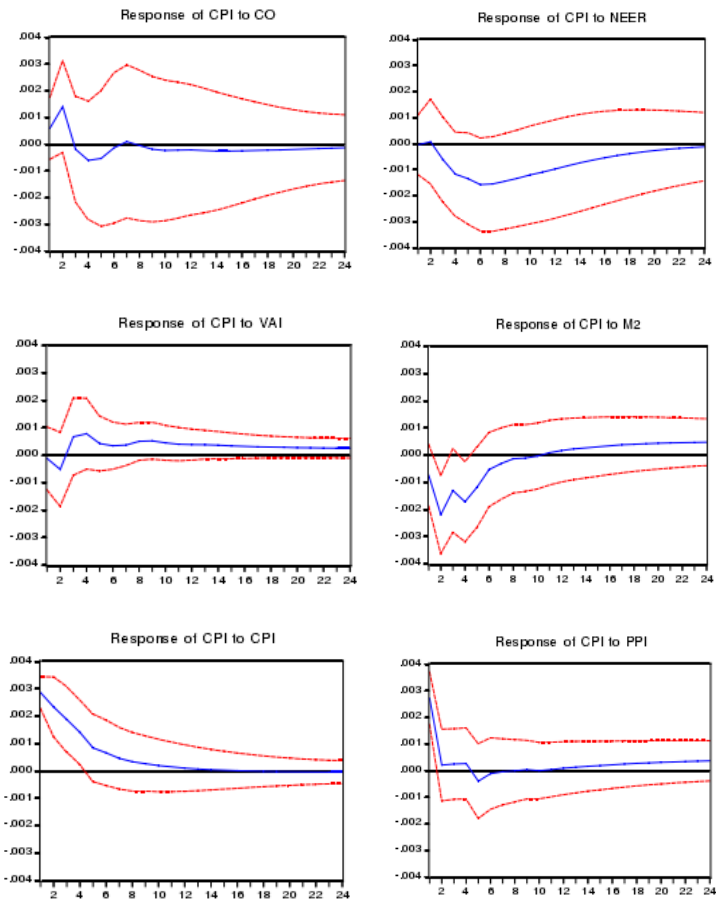

Fig. 4. Impulse Responses of CPI

\section{1) Short-term impulse response}

As is shown in Fig. 4, NEER has a negative impact on CPI on the whole. The impact is not significant in the first two phases, and the impact gradually increases, achieves the maximum value in the sixth phase and then continues to weaken, which demonstrates that the impact of RMB exchange rate fluctuation on domestic price is a long-term and continuous accumulation process. In addition, Fig. 4 presents impulse responses of CPI to other variables: $\mathrm{CO}$ has an immediate, positive and short-term impact on CPI. VAI firstly has a small and short-term negative impact and then exerts a long-term positive impact. M2 has a negative impact on CPI in the short term and the impact gradually weakens and turns into positive impact in the long term. PPI has a significant positive impact on CPI and the impact approaches zero in the fourth phase. CPI itself has a great impact on CPI, indicating that previous price fluctuations have a sustainable impact on subsequent prices.

\section{2) Middle- and Long-term impulse response}

The impulse response does not reflect middle-and longterm relations. In addition, the co-integration expressions do not reveal the relationship between PPI and exchange rate. According to the method of Feng [11], this paper calculates the accumulative impulse response. The T-month cumulative change of price after exchange rate shocks is divided by the Tmonth cumulative change of exchange rate, which is expressed as:

$$
P T_{t, t+T}=\sum_{j=1}^{T} \Delta P_{t, t+j} / \sum_{j=1}^{T} \Delta E_{t, t+j}
$$

Where ${ }^{\Delta P_{t, t+j}}$ represents the change rate of price $\mathrm{j}$ months after the exchange rate shocks; $\Delta E_{t, t+j}$ represents corresponding change rate of exchange rate. The index can intuitively reflect the changing trends of exchange rate passthrough effect with time.
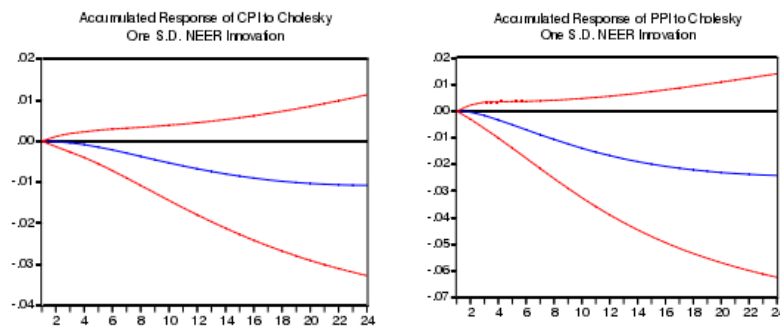

Fig. 5. Accumulative Impulse Responses of CPI and PPI to NEER

Fig. 5 shows that exchange rate pass-through exhibits increasing influence in the long term after the short-term insignificance. NEER has a greater impact on PPI than on CPI in the middle- and long-term.

\section{E. Pass-through Coefficient of Exchange Rate}

By using the method of Feng [11], this paper calculates exchange rate pass-through coefficient on PPI and CPI in different time lags and the results are demonstrated in Table 2.

TABLE III. EXCHANGE RATE PASS-THROUGH COEFFICIENTS

\begin{tabular}{|c|c|c|}
\hline Different time lags & PPI & CPI \\
\hline 4 & -0.036351 & -0.019152 \\
\hline 8 & -0.073793 & -0.047889 \\
\hline 12 & -0.108894 & -0.066706 \\
\hline 16 & -0.140952 & -0.076072 \\
\hline 20 & -0.172488 & -0.076521 \\
\hline 24 & -0.204211 & -0.078509 \\
\hline
\end{tabular}

The pass-through effect of RMB exchange rate has the following characteristics: the pass-through effect of NEER on PPI is stronger than that on CPI; exchange rate pass-through 
exhibits significant rigidity; the largest growth in the passthrough coefficient takes place in the long term.

\section{CONCLUSIONS}

It is concluded that the impact of RMB exchange rate fluctuation on the price level in Yunnan Province is a longterm process. RMB exchange rate appreciation decreases consumer price and industrial product price in Yunnan Province. The impact on producer price is more significant than that on consumer price.

Based on the empirical study, two suggestions are put forward:

- The industry in Yunnan should be upgraded and the structure of industry should be adjusted. The structure of import and export in Yunnan is unreasonable. The exported products are typically characterized by low technology, low added value and low bargaining power while the imported products are mostly high valueadded products. RMB appreciation significantly influences Yunnan's exported products and has little impact on the imported products. Yunnan should promote industrial upgrading, accelerate structural adjustment.

- The competitiveness of commodities produced in Yunnan should be strengthened. In Yunnan, it is recommended to adopt foreign trade policies to maintain competitiveness of domestic commodities in the short term. To maintain export stability, it is necessary to reduce the costs of export enterprises. Specifically, it is feasible to restrain increases in raw material prices and employee wages, and provide indirect subsidies for these export enterprises. To reduce the impact of RMB appreciation on importsubstituting industries, some measures can be taken to raise the costs of imports and indirectly reduce the elasticity of exchange rate on import substitutes.

This paper does not consider the nonlinear pass-through effects. The future research will pay more attention to the nonlinear impacts of increased exchange rate fluctuation on China's dual economic structure.

\section{ACKNOWLEDGMENT}

R. B. G. thanks Kunming Branch of the People's Bank of China, Yunnan University of Economics \& Finance, Professor Wang Zhiyong and the anonymous reviewers.

\section{REFERENCES}

[1] P. Bacchetta and E. Wincoop, "the Great Recession: a self-fulfilling global panic," American Economic Journal: Macroeconomics, No. 8(4), pp. 177-198, 2016.

[2] M. Bahmani-Oskooee and H Fariditavana, "Do exchange rate changes have symmetric effect on the S-curve?" Econ Bull, vol. 34, pp164-173, 2014.

[3] Bi Yujiang and Zhu Zhongyu, "the pass-through effect of RMB exchange rate changes on price: an empirical study based on cointegration and an error correction model," Journal of Financial Research, vol. 32(7), pp. 53 62, 2016.

[4] Bu Yongxiang, "the effect of change in RMB exchange rate on the domestic price," Journal of Financial Research vol. 3, pp. 78-88, 2001.

[5] Chen Liufu and Liu Houjun, "the pass-through effect of RMB exchange rate on price - an empirical analysis based on VAR model," Journal of Financial Research, vol.4, pp. 1-13, 2007.

[6] E.U. Choudhri and D.S. Hakura, "the exchange rate pass-through to import and export prices: the role of nominal rigidities and currency choice," Journal of International Money and Finance, vol. 51, pp. 1-25, 2015 .

[7] M.B. Devereux and J. Yetman, "Price-setting and exchange rate passTthrough: theory and evidence in price adjustment and monetary policy," the American Economic Review, vol. 4, pp47-71, 2013.

[8] M.B. Devereux, C. Engel and P.E. Storgaard, "Pass-through of exchange rates and import prices to domestic inflation in some industrialized economies," BIS working papers 11/79, BIS Committee, 2014.

[9] Fan Zhiyong and Xiang Dihai, "the impact of exchange rate and price shocks from the international markets on domestic price fluctuations," New West, vol.2, pp. 36-43, 2016.

[10] H. Faruqee, "Exchange rate pass-through in the Euro area: the role of asymmetric pricing behavior," IMF Working Papers 04/34, International Monetary Fund, 2004.

[11] Feng Beilin, "the pass-through effects of exchange rate and macroeconomic shocks on inflation," World Economy Study, vol. 12, pp 45 51, 2016.

[12] $\mathrm{Hu}$, Ridong and $\mathrm{Li}$, Wenxing, "the pass-through effect of RMB exchange rate on price after the reform of exchange rate: taking the reform of exchange regime in July 2005 as the threshold," Macroeconomics, vol. 9, pp. 61-67, 2011.

[13] Jin Shan and Wang Qianyuan, "the pass-through effect of external shock and China's inflation_an empirical analysis based on VAR model,' Finance and Trade Economy, vol.11, pp. 90-97, 2004.

[14] C.Z. Michele, H. Elke and S. Marcelo, "Exchange rate pass-through in emerging markets," the IUP Journal of Monetary Economics, vol. 0(4), pp. 84-402, 2007.

[15] J.B. Taylor, "Low inflation, pass-through and the pricing power of firms," European Economic Review, vol. 44, pp. 1389-1408, 2010

[16] Wang Jinbin and Li Nan, "An empirical analysis of China's exchange rate pass-through effect," Economic Research Journal, vol.4, pp. 17-27, 2015 .

[17] Zhu Lu and Yu Lina, "Research on the pass-through effect of effective exchange rate fluctuations on domestic prices," World Economy Study, vol.6, pp. 38-42, 2015. 